\title{
Respiratory cancer in Danish bakers: a 10 year cohort study
}

\author{
F TÜCHSEN AND L NORDHOLM
}

From the Danish National Institute of Occupational Health, DK-2900 Hellerup, Denmark

ABSTRACT A national cohort based on the census at 9 November 1970 and the death registration files from 1970 to 1980 was analysed to see if skilled Danish bakers had an excess of respiratory cancer. The group of skilled bakers was divided into occupational subgroups to try to narrow down the possible causes of cancer. Significant excess mortality was found among skilled bakers in retail bakeries, skilled bakers in hotels and restaurants, and independent bakers. To adjust for confounding factors, the SMR was calculated with control groups of equal social status and smoking habits. With all skilled workers as the reference group, skilled bakers in retail bakeries still had an excess, but now insignificant, risk but skilled bakers in hotels and restaurants had a significant excess risk. Compared with all self employed people in urban occupations in which an average of six or fewer workers were employed as a referent group, independent bakers had an insignificant excess risk. Suspected carcinogens in bakeries include polycyclic aromatic hydrocarbons (PAH), reaction products of $\mathbf{P A H}$, free radicals, n-nitrosodimethylamine, aflatoxine, sterigmatocystin, and zeralenone.

During the past 20 years an excess risk of lung cancer has been found in bakers and in cooks. A significant excess or morbidity or mortality from lung cancer in bakers has been reported by the Office of Population Censuses and Surveys, ${ }^{1}$ Menck and Henderson, ${ }^{2}$ Lynge, ${ }^{34}$ Tüchsen, ${ }^{56}$ Hogstedt et al, ${ }^{7}$ and Coggon. ${ }^{8}$ In two studies no excess risk was found, ${ }^{910}$ and in another Acheson et al have reported an insignificant excess risk of nasal cancer. ${ }^{11} \mathrm{~A}$ significant excess of lung cancer in cooks has been found in several studies $^{134812-14}$

The purpose of the present study was to investigate the mortality from lung cancer in bakers and to determine which subgroups among bakers accounted for the excess.

\section{Material and methods}

The study is based on a 10 year cohort file made by the Danish national bureau of statistics, Danmarks Statistik. The cohort includes everyone aged 20 to 64 in Denmark at 9 November 1970. Of 1401967 men, 1229337 were economically active: $\mathbf{3 4 1 8}$ men were in independent bakeries, 4048 men were skilled bakers

Accepted 23 September 1985 employed in retail bakeries, 669 were skilled bakers in bread and cake factories, and 102 were skilled bakers in hotels and restaurants. No analyses were made on female skilled bakers because only 79 were so employed with a further 153 in independent retail bakeries.

In the 10 year follow up period 91638 economically active men died. The cohort is based on three sources: (1) the census of 9 November 1970, (2) data as of 1 January 1981 from the Central Population Register (CPR), and (3) the death registration files from 1970 to 1980 .

The CPR contains information about everyone who has resided in Denmark since the foundation of the register in 1968. Each person has a permanent personal identification number, the CPR number.

The census data were registered according to CPR numbers. By matching the census file and the CPR file everyone in the census population who died, emigrated, or disappeared during the 10 year period 9 November 1970 to 8 November 1980 has been identified.

The death registrations from 1973 to 1980 containing medical information were also registered according to CPR number. The cause of death for those in the census population dying between 1 January 1973 and 8 November 1980 could therefore be found by matching the death registration files with the com- 
bined census CPR file.

The occupations registered at census are coded according to a Danish occupational code including 218 numbers and the industries are coded according to a Danish revision of International Standard Industrial Classification of all Economic Activities (ISIC) 1968. The classification includes 245 numbers.

The registration of causes of death is based on the 8 th revision of the International Classification of Diseases (ICD). This study includes ICD diagnoses 160 to 163 .

The study is based on age specific death rates for five year age groups. The death rates have been used for calculating the standardised mortality ratio (SMR). To make international comparisons possible the SMR was first calculated with all economically independent active men as the control group. To adjust for social status, the SMR for skilled bakers has been calculated with all skilled workers as the reference group. Independent bakers have been compared with all non-academic self employed workers in urban occupations in which an average of one to six workers was employed.

A survey including a representative sample of all Danish trade union members was carried out in $1973^{15}$ from which the fraction of smokers in each trade union may be compared. In 1981 the independent trade unions of bakers, mill workers, and confectioners merged into one union. In 1982 we carried out a survey including 1782 of its members ${ }^{6}$ and from this survey smoking habits of the occupational subgroups are known. From a third survey, the smoking habits of all skilled workers and of the entire Danish population are known between 1958 and $1976 .{ }^{16}$ By calculating the SMR for skilled bakers, using all skilled workers as the control population, we were able to adjust for the confounding factor of smoking for skilled bakers. For independent bakers the smoking habits are not known, but they are estimated to be the same as those of other self employed workers in urban occupations with fewer than six employees.

\section{Results}

To make comparisons with other investigations possible, SMR has been calculated using all economically active men in Denmark as the control group. For all the groups investigated, except skilled bakers employed in bread and cake factories, the mortality exceeds the mortality of all economically active men in Denmark.

For skilled bakers employed in retail bakeries, the SMR is 178, which is significantly higher than 100 (p $=0.00008$ ). For the small group of skilled bakers employed in hotels and restaurants the SMR is 543 (p $=0.00002$ ), and for the independent bakers the SMR is $146(p=0.007)$. For skilled bakers employed in bread and cake factories the SMR is 81 but does not differ significantly from $100(p=0.65)$. For all skilled bakers working in small plants SMR is 136 ( $p<$ 0.000001) (table 1).

We have reanalysed a survey carried out in 1973 that included a representative sample of $\mathbf{4 5 7 2}$ male labour union members in order to compare the smoking habits of the bakers with those of other workers. Twenty one $(32 \%)$ of the bakers were non-smokers whereas $1330(29 \%)$ of all the respondents were nonsmokers. The difference is not significant $\left(\chi^{2}=0.24\right.$ and $\mathrm{p}=0.63$ ).

In 1982 we made a representative survey of all members of the Bakers', Confectioners', and Mill Workers' Trade Union in Denmark. Practically all workers are organised and the response rate was $64 \%$. Some of the respondents were not willing to tell the name of the firm but the number of male respondents in firms that were identifiable in the industry file in Denmark's statistical bureau was 974, $88 \%$ of the respondents. Table 2 shows the smoking habits.

The highest proportion of heavy smokers is found in bread and cake factories where no excess mortality from lung cancer was found. Relatively few heavy smokers were found among bakers in hotels and res-

Table 1 SMR for cancer of the respiratory tract for skilled bakers 1970-80

\begin{tabular}{|c|c|c|c|c|c|}
\hline \multirow[t]{2}{*}{ Occupations } & \multirow{2}{*}{$\begin{array}{l}\text { Risk population } \\
9 \text { Nov } 1970\end{array}$} & \multicolumn{3}{|c|}{ Deaths } & \multirow{2}{*}{$\begin{array}{l}95 \% \text { Confidence } \\
\text { limits }\end{array}$} \\
\hline & & Obs & $\operatorname{Exp}$ & $S M R$ & \\
\hline \multirow{2}{*}{$\begin{array}{l}\text { Skilled bakers in: } \\
\text { Retail bakeries } \\
\text { Hotels and restaurants } \\
\text { Independent bakers in: } \\
\text { Retail bakeries }\end{array}$} & $\begin{array}{r}4048 \\
102\end{array}$ & $\begin{array}{r}45 \\
5\end{array}$ & $\begin{array}{r}25.2 \\
0.9\end{array}$ & $\begin{array}{l}178 \\
543\end{array}$ & $\begin{array}{l}(129-236) \\
(170-1164)\end{array}$ \\
\hline & 3418 & 50 & $34 \cdot 2$ & 146 & $(108-190)$ \\
\hline All bakers in small plants & 7568 & 100 & $60 \cdot 3$ & 166 & $(134-201)$ \\
\hline $\begin{array}{l}\text { Skilled bakers in: } \\
\text { Cake factories } \\
\text { All skilled bakers }\end{array}$ & $\begin{array}{r}669 \\
8237\end{array}$ & $\begin{array}{r}5 \\
105\end{array}$ & $\begin{array}{r}6 \cdot 1 \\
66 \cdot 4\end{array}$ & $\begin{array}{r}82 \\
158\end{array}$ & $\begin{array}{l}(25-171) \\
(129-191)\end{array}$ \\
\hline
\end{tabular}

Control group: all economically active men in Denmark. 
Table 2 Cigarette smoking among male skilled bakers employed in bread and cake factories, retail bakeries, and hotels and restaurants, 1981

\begin{tabular}{lcccc}
\hline & $\begin{array}{l}\text { Bread and cake } \\
\text { factories }(\%) \\
(n=183)\end{array}$ & $\begin{array}{l}\text { Retail bakeries } \\
(\%)\end{array}$ & $\begin{array}{l}\text { Hotels and restaurants } \\
(\%=756)\end{array}$ & $\begin{array}{l}\text { All bakers } \\
(\%)\end{array}$ \\
$(n=35)$ & $974)$ \\
\hline $\begin{array}{l}\text { Non-smokers } \\
\text { No of cigarettes a day: }\end{array}$ & 50 & 55 & 51 & 54 \\
$\begin{array}{l}1-14 \\
15-43\end{array}$ & 24 & 25 & 32 & 25 \\
Total & 26 & 20 & 17 & 21 \\
\hline
\end{tabular}

$\chi^{2} 4 \cdot 18, \mathrm{DF}=4, p=0 \cdot 38$

taurants where the excess mortality from lung cancer was most pronounced, but none of the differences is significant. The smoking habits of the independent bakers are unknown.

The excesses of mortality shown in table 1 may partly be explained by confounding factors such as smoking habits and social status. To adjust for such confounders, the SMR has been calculated with other reference groups. For skilled bakers all skilled workers have been used as a control group and for the independent bakers the reference group consisted of all self employed men in urban occupations with an average number of one to six employees.

Skilled bakers in hotels and restaurants still have a significant excess mortality compared with all skilled workers, the SMR being $383(\mathrm{p}=0.002)$. For skilled bakers employed in retail bakeries, the SMR is 134 (p $=0.05)$; the SMR for independent bakers is $129(\mathrm{p}=$ 0.08 ). A significant excess risk is found for all skilled bakers working in small plants (SMR 136; $\mathrm{p}=$ 0.0033\%; see table 3).

\section{Discussion}

Misclassification of cause of death may be a source of bias. If clinicians had believed during the study period that bakers had an excess risk of cancer in the respiratory system it might have facilitated this diagnosis in the exposed groups and thus increased the SMR. But it was not known and it is still not widely accepted so that it is unlikely that the diagnosis of cause of death was biased on this account.

In $1975,49.9 \%$ of all those dying in Denmark in the age group 25 to 74 had a necropsy. ${ }^{17}$ Death due to cancer of the respiratory tract is little influenced by "healthy worker" effect, ${ }^{18}$ and even though death certificates in general contain some misclassifications, cancer of the respiratory tract is so well diagnosed that this could not influence the results of the present study.

One of the most important confounding factors in studies of occupational lung cancer is smoking. In the 1973 trade union survey no more smokers were found among bakers than among other skilled workers. From our 1982 survey we know that $52 \%$ of all employed skilled bakers did not smoke cigarettes. Six years earlier, a national survey had shown that only $44 \%$ of the unskilled workers and $50 \%$ of the skilled workers did not smoke cigarettes. ${ }^{16}$ In the 1982 survey the small differences found in smoking habits are in favour of the occupational subgroups in whom we found excesses of respiratory cancer. Thus it may be concluded that the excesses of lung cancer found in some subgroups of bakers are not likely to be due to differences in smoking habits.

Excess risks of lung cancer in bakers have been

Table 3 SMR for cancer of the respiratory tract for skilled bakers 1970-80

\begin{tabular}{|c|c|c|c|c|c|}
\hline \multirow[t]{2}{*}{ Occupations } & \multirow{2}{*}{$\begin{array}{l}\text { Risk population } \\
9 \text { Nov } 1970\end{array}$} & \multicolumn{3}{|c|}{ Deaths } & \multirow{2}{*}{$\begin{array}{l}95 \% \text { Confidence } \\
\text { limits }\end{array}$} \\
\hline & & Obs & $\operatorname{Exp}$ & $S M R$ & \\
\hline $\begin{array}{l}\text { Skilled bakers }{ }^{*} \text { in: } \\
\text { Retail bakeries } \\
\text { Hotels and restaurants }\end{array}$ & $\begin{array}{r}4048 \\
102\end{array}$ & $\begin{array}{r}45 \\
5\end{array}$ & $\begin{array}{r}33 \cdot 7 \\
1 \cdot 3\end{array}$ & $\begin{array}{l}134 \\
383\end{array}$ & $\begin{array}{l}(97-176) \\
(118-806)\end{array}$ \\
\hline Retail bakeries & 3418 & 50 & $38 \cdot 8$ & 129 & $(95-168)$ \\
\hline All bakers in small plants & 7568 & 100 & $73 \cdot 8$ & 136 & $(110-164)$ \\
\hline $\begin{array}{l}\text { Skilled bakers* in: } \\
\text { Cake factories } \\
\text { All skilled bakers }\end{array}$ & $\begin{array}{r}669 \\
8237\end{array}$ & $\begin{array}{r}5 \\
105\end{array}$ & $\begin{array}{r}8 \cdot 3 \\
82 \cdot 1\end{array}$ & $\begin{array}{r}61 \\
128\end{array}$ & $\begin{array}{l}(18-126) \\
(104-154)\end{array}$ \\
\hline
\end{tabular}

*Control group: all skilled workers.

†Control group: all independent in urban occupations. 
reported in several countries. In a study based on the 1971 census in England and Wales bakers and pastry cooks were found to have an excess mortality risk due to malignant neoplasms. For malignant neoplasms in the trachea, bronchi, and lung the SMR was 128 for the years 1970-2. For malignant neoplasms in the stomach the SMR was $147 .^{1}$ In a case referent study Menck and Henderson reported an excess mortality for bakers compared with all industrial workers in Los Angeles County (SMR 169). ${ }^{2}$ Their study comprised 2161 death certificates with lung cancer in white men, aged 20 to 64, between 1968 and 1970. In Sweden Hogstedt $e t$ al reported an excess incidence of laryngeal cancer in male bakers. ${ }^{7}$ The relative risk was 1.4 between 1961 and 1973 and 1.1 between 1974 and 1979. The incidence of lung cancer in male bakers decreased from 1.6 in the first period to 1.2 in the second. In female bakers the relative risk for lung cancer was $2 \cdot 1$ between 1961 and 1973 but only 1.2 between 1974 and 1979. Smoking habits in 1963 should explain about $5 \%$ of the excess risk. ${ }^{7}$ In a new case referent study Coggon et al found a significant excess of deaths from lung cancer in cooks, pastry cooks, and bakers in England and Wales. ${ }^{8}$

These studies are in line with the findings of the present investigation but two other studies have come to different conclusions. In a cohort study matching occupational data of 6424 union members-asbestos workers, male and female bakers, painters, plasterers, plumbers, and roofers-with cases of cancer in the cancer incidence system master file maintained by the California Tumor Registry, Lassiter et al found no excess risk from cancer in bakers. ${ }^{9}$ The study covered the years 1976 and 1977. The expected incidence was obtained from the San Francisco-Oakland standard metropolitan statistical rates since 1976. Reexamining morbidity and mortality among 399 bakers and 398 butchers in Hamburg, Doerken and Rehpenning found only half as many lung cancers in the respiratory tract in bakers as in butchers for the period 1954 to $1966 .{ }^{10}$

None of the studies mentioned above has split the data into occupational subgroups. The proportions of retail bakeries would possibly differ widely in various countries. Many bakers working in factories had formerly worked in retail bakeries. Probably, therefore, the difference in mortality has been underestimated in the present study and it is not unlikely that differences in mortality in various countries are also mainly due to this fact.

In Sweden the industrialisation of bakeries started some years before it started in Denmark, and the development has been more pronounced. The relative decrease in lung cancer morbidity among bakers in Sweden may be due to this fact. In a national survey of nasal cancer in England and Wales Acheson et al reported an excess of uncertain significance among bakers and pastry cooks. ${ }^{11}$

Bakers and cooks have several working conditions in common. Both groups work abnormal hours, and they handle flour, butter, milk, and eggs.

Using a job exposure matrix in a case control study, Coggon et al have found an excess risk for carcinoma of the bronchus among cooks; the relative risk was 6.7. ${ }^{12}$ An earlier Danish study by Lynge showed that skilled bakers and cooks had an excess lung cancer mortality in the years 1970 to $1975 .^{34}$ In a more detailed analysis of the same cohort we found that the excess risk was concentrated among skilled bakers in retail bakeries who had an SMR of 224. Self employed bakers had an insignificant excess risk (SMR 137). No excess risk of cancer of the respiratory tract was found in unskilled male workers in bread and cake factories or mills, nor in female workers in bakeries, bread and cake factories, or mills. ${ }^{56}$ In the 10 year cohort the SMR due to cancer of the respiratory tract for cooks was $252 .{ }^{14}$

\section{SUSPECTED CARCINOGENS IN BAKERIES}

At least four hypotheses concerning the nature of carcinogens in bakeries may be drawn up. None has been confirmed.

(1) Menck and Henderson suggested in 1976 that polycyclic aromatic hydrocarbons (PAH) might cause lung cancer in bakers. ${ }^{2}$ PAH may be formed through pyrolysis in the baking ovens. In our previous investigation we found little PAH-benzo(a)pyrene (BaP) (9 ng) 1, 2, 5, 6-dibenzantracene $(10 \mathrm{ng})$, benzo(j)fluoranthene $(40 \mathrm{ng})$ and benzo(b)fluoranthene $\left(26 \mathrm{ng}\right.$ per $\mathrm{m}^{3}$ air)-in a gas heated baking oven in a cake factory. ${ }^{5}$ Possibly some PAH may have been transformed into oxidised products, some of which are known to be more potent carcinogens; none of these PAH derivatives was included in our analysis, however.

In connection with the present studies four bakeries equipped with the different types of oven common in Danish bakeries today were investigated for 16 priority PAH pollutants. ${ }^{19}$ Air samples were taken at the top of the oven door using the Danish National Institute of Occupational Health standard procedure for sampling and analysis of PAH. The detection limits, ranging from 0.05 to $0.2 \mu \mathrm{m}$ per $\mathrm{m}^{3}$, were in no case exceeded.

This does not prove that lung cancer in bakers is not caused by PAH but it is unlikely that modern baking ovens produce so much PAH that an excess risk of lung cancer can be explained in this way. Today it is not possible to measure the PAH production in coke heated ovens. Coke heated ovens were widely used in the 1950s and even in the begin- 
ning of the 1960s. Even if it was the case that PAH exposure was high until the mid 1960s, however, we would expect that the excess risk of lung cancer would have decreased during the later 1960s and that the risk would have reached the average in the middle of the 1970s. No such decrease in lung cancer mortality was found, however.

This hypothesis agrees with the finding of no lung cancer mortality in mill workers, few deaths among skilled bakers employed in cake and bread factories, and excess mortality in skilled bakers and independent bakers in retail bakeries. The decreasing incidence of lung cancer in bakers, found in Sweden, fits well with the rapid decrease in the number of retail bakeries in Sweden. The excess risk for cooks and bakers working in restaurants may also be due to PAH. For employees in restaurants the occupational exposure to PAH is considerable. The concentration of $\mathrm{BaP}$ in the working atmosphere varies from $30 \mathrm{ng} / \mathrm{m}^{3}$ air up to $140 \mathrm{ng} / \mathrm{m}^{3}$ air in restaurants in the United States. This quantity will result in a daily intake of $800 \mathrm{ng} \mathrm{BaP}$ for employees in restaurants. ${ }^{2021}$ The sources are cooking and smoking.

(2) Fat, which is not pyrolysed into PAH, may nevertheless be transformed into free radicals known to be potent carcinogens.

(3) Some micro-organisms such as Aspergillus flavus, Aspergillus parasiticus, Aspergillus nidulans, and Aspergillus versicolor, which may be found in grain, bread, and bakery moulds, are known for their ability to produce aflatoxin and sterigmatocystin which are both potent carcinogens. ${ }^{22-25}$ Zeralenone is produced primarily by members of the Fusaria group and has been found in cereal products in Italy, in wheat in Hungary, ${ }^{26}$ and in grain dust in the New Orleans area in the USA. $^{27}$ Zeralenone has been tested for carcinogenicity in rats and mice. There is limited evidence for carcinogenicity in experimental animals. ${ }^{26}$

Forced ventilation usually brings the humidity in bread and cake factories down to low levels. In retail bakeries this is not usually so. Therefore, it is possible to find moulds in retail bakeries but usually not in factories or in mills. Ten per cent of the respondents in the 1982 survey reported visible moulds in their working place.

(4) Uibu et al have shown that at least seven strains of micro-organisms found in raw materials used in bakeries can produce nitrosodimethylamine (NDMA) in Hiltey medium. ${ }^{28}$ The conditions seem to be far different from those found in bakeries, but we do not know whether or not NDMA is present in bakeries.

The fact that no death from lung cancer has been observed among mill workers does not necessarily mean that micro-organisms are not responsible for the lung cancer mortality in bakers. The humidity in bakeries is often high and enables fungi to grow and produce toxins.

In Germany grain is sterilised before it is soaked but this process is not widely used in Denmark, especially not in retail bakeries. So, if fungi in fact are a source of lung cancer in bakers we would expect a lower mortality from lung cancer in Germany compared with Denmark, which is actually confirmed by the findings of Doerken and Rehpenning. ${ }^{10}$

If any of the hypotheses concerning carcinogens produced by fungi are true then prevention should be possible. For reasons of hygiene it is also important to reduce the number of micro-organisms in grain and to prevent moulds in bakeries. Exposure to grain dust must be reduced especially in order to reduce the risk of grain dust allergy.

We thank the Jutlands Technological Institute, Arhus, and Danish Labour Inspection Service, Hillerød, Denmark, for collecting air samples.

Requests for reprints to: Finn Tüchsen, Danish National Institute of Occupational Health, Baunegaardsvej 73-75, DK-2900 Hellerup, Denmark.

\section{References}

${ }^{1}$ Office of Population Censuses and Surveys. Occupational mortality 1970-72. Decennial supplement for England and Wales. London HMSO, 1978. (Series DS No 1.)

${ }^{2}$ Menck HR, Henderson BE. Occupational differences in rates of lung cancer. J Occup Med 1976;18:797-801.

${ }^{3}$ Danmarks Statistik. Dodelighed og erhverv 1970-5. Copenhagen: Danmarks Statistik, 1979. (Statistiske undersøgelser No 37.)

${ }^{4}$ Lynge E. The Danish occupational cancer study. In: Prevention of occupational cancer: international symposium proceedings. Geneva: International Labour Office, 1982.

${ }^{5}$ Tüchsen F. Arbejdsmiljøet $i$ bagerier, konditorier, mollerier og biscuitsfabrikker-Dodelighed 1970-1975. Institut for social medicin, Københavns Universitet, Fagbevægelsens Forskningsråd og Arbejdsmiljøfondet, 1981.

${ }^{6}$ Tüchsen F, Detlif C. Bagernes arbejde og helbred. Om arbejdsmiljoet $i$ bagerier, konditorier, mollerier og biscuitsfabrikker. Institut for social medicin, Københavns Universitet, Fagbevægelsens Forskningsråd og Arbejdsmiljøfondet, 1982.

${ }^{7}$ Hogstedt C, Carstensen J, Svenson E, et al. Luftvägscancer hos slagters och bagara - bearbetningar av cancermiljöregistret och rökvaneundersökningen. Läkaresällskapets Riksstämma 1983; Nov 30 to Dec 2.

${ }^{8}$ Coggon D, Pannett B, Osmond C, Acheson ED. A survey of cancer and occupation in young and middle aged men. I. Cancers of the respiratory tract. $\mathrm{Br} J$ Ind $\mathrm{Med}$ 1986;43:332-8.

${ }^{9}$ Lassiter DV, Schulman J, Siqueira SL, et al. The feasibility of using a population-based tumor registry to identify occupational industrial cohorts at elevated risks of developing cancer. Cincinnati: US Department of Health and Human Services Public Health Service, Center for Disease Control, NIOSH, Hazard Evaluations and Field Studies, 1980.

${ }^{10}$ Doerken H, Rehpenning W. Lung cancer in butchers. Lancet 1982;i:561.

${ }^{11}$ Acheson ED, Cowdell RH, Rang EH. Nasal cancer in England 
and Wales: an occupational survey. $\mathrm{Br} J$ Ind Med 1981;38:218-24.

${ }^{12}$ Coggon D, Pannett B, Acheson ED. Use of job-exposure matrix in an occupational analysis of lung and bladder cancer on the basis of death certificates. JNCI 1983;72:61-5.

${ }^{13}$ Milham S. Occupational mortality in Washington State 1950-71. Washington: US Government Printing Office, 1976. (DHEW publication No 76-175.)

${ }^{14}$ Andersen O. Dodelighed og erhverv 1970-80. Copenhagen: Danmarks Statistik, 1985. (Statistiske undersøgelser No 41.)

${ }^{15}$ Arbejdsmiljøundersøgelsen. Copenhagen: Arbejdsmiljøfondet, 1974.

${ }^{16}$ Nielsen PE, Krarup NB, Astrup J, et al. Endring i danskernes rygevaner 1958-76. Ugeskr Laeger 1979;140:2528-32.

${ }^{17}$ Asnæs S. Obduktionens betydning for bestemmelse af dodsårsager og dodsmåder. Copenhagen: University of Copenhagen, 1984. (Thesis.)

${ }^{18} \mathrm{McMichael}$ AJ. Standard mortality ratios and the "healthy worker effect," scratching beneath the surface. J Occup Med 1976; 18:165-8.

${ }^{19}$ Keith LH, Tellard WA. Priority pollutants. I-a perspective view. Environ Sci Technol 1979;13:416-23.

${ }^{20}$ Schmeltz A, Hoffman ID, Wynder EL. The influence of tobacco smoke on indoor atmospheres. Prev Med 1975;4:66-82.

${ }^{21}$ Bridbord K, Finklea JF, Wagoner JK, et al. Human exposure to polynuclear aromatic hydrocarbons. In: Freudenthal RI, Jones PW, eds. Carcinogenesis. Vol 1. Polynuclear aromatic hydrocarbons: chemistry, metabolism, and carcinogenesis. New York: Raven Press, 1976:319-24.

${ }^{22}$ Zennie TM. Identification of aflatoxin $B_{1}$ in grain elevator dusts in central Illinois. J Toxicol Environ Health 1984;13:589-93.

${ }^{23}$ Gemeinhardt H, Bergmann I. Zur Vorkommen von Schimmelpilzen in Bäckereistäuben $=$ moulds in bakery dust. Zentralbl Bakteriol 1977;132/II:44-54.

${ }^{24}$ Dich J, Åkerstrand K, Anderson A, et al. Konserveringsmedels Förekomst och inverkan pả mögel- och mykotoxininbildning i matbröd. Vär Föda 1979;31:385-403.

${ }^{25}$ Chan-Yeung M, Ashley MJ, Grzybowski S. Grain dust and the lungs. Can Med Assoc J 1978;118:1271-4.

${ }^{26}$ International Agency for Research on Cancer. Monographs on the evaluation of carcinogenic risk of chemicals to humans. Vol 31. Some food additives, feed additives and naturally occurring substances. Lyon: IARC, 1983.

${ }^{27}$ Palmgren MS, Lee LS, Delucca AJ, et al. Preliminary study of mycoflora and mycotoxins in grain dust from New Orleans area grain elevators. Am Ind Hyg Assoc J 1983;44:485-8.

${ }^{28}$ Uibu J, Bogovski P, Tauts O. Formation of nitrosodimethylamine by microorganisms used in baking industry or isolated from the raw materials of bakery products. IARC Sci Publ 1978;19: 247-56.

\section{Destruction of manuscripts}

From 1 July 1985 articles submitted for publication will not be returned. Authors whose papers are rejected will be advised of the decision and the manuscripts will be kept under security for three months to deal with any inquiries and then destroyed. 